ANADOLU, J. of AARI

ISSN: $1300-0225$ (Print)

E-ISSN: 2667-6087 (Online)

2021, 31 (2): 180-193

DOI: $10.18615 /$ anadolu. 1030058

\title{
Farklı Arazi Örtüsünün Arazi Degradasyonu Üzerine Etkileri: Çanakkale Çıplak Köyü Örneği
}

\author{
Timuçin EVEREST ${ }^{1}$ \\ Ali SUNGUR $\mathbb{R}^{2}$ \\ Mehmet PARLAK \\ Erdem TEMEL ${ }^{4} \mathbb{D}$ Hasan ÖZCAN ${ }^{5}$ \\ ${ }^{1,3}$ Çanakkale Onsekiz Mart Üniversitesi, Lapseki Meslek Yüksekokulu, Çanakkale/ TURKEY \\ ${ }^{2,4,5}$ Çanakkale Onsekiz Mart Üniversitesi, Ziraat Fakültesi, Toprak Bilimi ve \\ Bitki Besleme Bölümü, Çanakkale/ TURKEY \\ $\begin{array}{ll}{ }^{1} \text { https://orcid.org/0000-0002-3670-2114 } & { }^{2} \text { https://orcid.org/0000-0002-2943-9207 } \\ { }^{3} \text { https://orcid.org/0000-0002-4813-1152 } & { }^{4} \text { https://orcid.org/0000-0001-8028-0716 }\end{array}$ \\ ${ }^{5}$ https://orcid.org/0000-0002-3476-1241 \\ *Corresponding author (Sorumlu yazar): timucineverest@comu.edu.tr \\ Received (Geliş tarihi):15.02.2021Ａccepted (Kabul tarihi): 16.08.2021
}

\begin{abstract}
ÖZ: Bu çalışma, Çanakkale-Karamenderes ovasının fluviyal taşkın düzlüğü üzerinde oluşmuş ve benzer özelliklere sahip fakat farklı arazi örtüsünün bulunduğu üç farkl parselde gerçekleştirilmiştir. Çalışmada arazi örtüsündeki değişimin toprakların fiziko-kimyasal özellikleri ve ağır metal içerikleri üzerine olan etkileri incelenmiştir. Amaç doğrultusunda 15 yıldır misır tarımı yapılan arazi (P1), 7 yıldır mısır tarımı yapılan arazi (P2) ve münavebeli tarımın yapıldı̆̆ parsel seçilmiştir. Taksonomik incelemeler neticesinde (P1)'de önemli düzeyde sıkışma ve pulluk altı katmanının oluştuğu belirlenmiştir. Analiz sonuçlarına göre (P1) profilinde hacim ağırlığında \%12'lik artış yaşanırken, diğer parsellerde bu artışın $\% 7,5(P 2)$ ve \%8,6 (P3) olduğu görülmüştür. Çalışma sonuçları ağır metallerin önemli derecede litolojiden etkilendiği fakat Cd ve kısmen Pb'nin antropojenik kaynaklardan etkilendiğine işaret etmiştir. Cd elementinin konsantrasyonları her ü̧̈ parselde kritik değerlerin üzerinde bulunmuş ve toprakların Cd ile kontamine olduğu belirlenmiștir. Diğer yandan, Pb'nin birinci derece kaynă̆ litoloji olmakla beraber antropojenik kaynaklardan da (emisyonlar ve tarımsal üretimde kullanılan kimyasallar) etkilenmiş olabileceğini gösterilmiştir. Jeobirikim indeksine göre yapılan değerlendirmede bu sonuçları desteklemiștir. Sonuc olarak 15 yıl ard arda misır tarımı yapılan parselde toprağın bazı fiziksel ve kimyasal özelliklerinde (özellikle sıkışma, Cd ve Pb içeriği) değişim olduğu ortaya konmuştur.
\end{abstract}

Anahtar kelimeler: Ă̆ır metal, arazi kullanım türü, degradasyon, monokültür tarım.

\section{Effects of Different Land Cover on Land Degradation: The Case of Çanakkale Çıplak Village}

ABSTRACT: This study was carried out in the Fluvial Flood Plain of Çanakkale-Karamenderes plain. The parcels on which the study was carried out have similar characteristics and have different land cover. In the study, we examined how land use type affects the physicochemical properties and heavy metal contents of soils. For this purpose, three different parcels were selected, namely, the land where maize has been cultivated for 15 years (P1), the land where maize has been cultivated for 7 years (P2), and the land where alternate agriculture has been carried out (P3). As a result of taxonomic survey, it was determined that a significant level of compaction and plowed layer occurred in (P1). Analysis results showed that there was an increase of $12 \%$ in bulk density in (P1). On the other hand, it was observed that this increase was lower in other parcels: $P 2$ (7.5 $\%)$ and $P 3(8.6 \%)$. The results of the study indicated that heavy metals were significantly affected by lithology, but Cd and 
partial $\mathrm{Pb}$ were affected by anthropogenic sources. The concentrations of $C d$ were found to be above the critical values in all three parcels, and it was determined that the soils were contaminated with $\mathrm{Cd}$. In addition, the results showed that although the primary source of $\mathrm{Pb}$ is lithology, it may have been affected by anthropogenic sources (emissions and chemicals used in agricultural production). The evaluation of the geoaccumulation index also supported these results. As a result, it was revealed that some physical and chemical properties of soil (especially compaction, $\mathrm{Cd}$, and $\mathrm{Pb}$ content) were changed in the parcel where maize cultivation was carried out for 15 consecutive years.

Keywords: Heavy metals, land use type, degradation, monoculture agriculture.

\section{GíRiş}

Arazi degradasyonu fiziksel bir müdahaleyle veya arazi kullanım değişiminin etkisiyle ya da her ikisinin de birlikte etkisi ile oluşan, arazide biyolojik ve ekonomik üretkenliğinin azalması veya kaybedilmesi olayıdır (Salih ve ark., 2017). Arazi degradasyonu; üretkenlik ile çevresel kalite üzerinde uzun zamanda etki eden, toprak kalitesini olumsuz yönde etkileyen ve küresel boyutlara ulaşmış bir tehdittir (Doran ve Parkin, 1994; Gibbs ve Salmon, 2015; Prăvălie ve ark., 2017).

Topraklar sınırlı doğal kaynaklar olup kaybedildiğinde geri kazanılmaları mümkün değildir. Günümüzde tarım arazileri son sınırına ulaşmıştır. $\mathrm{Bu}$ nedenle artan nüfusun gereksinimlerini karşılamak için topraklar üzerinde çok ciddi baskı unsurları bulunmaktır. Bunlardan ilki toplumların beslenme ihtiyacını karşılamak için birim alandan daha yüksek verim alma kaygısı, ikincisi ise insanların barınma, eğitim, sağlık, ulaşım, istihdam olanakları sağlanması vb. tarım dışı taleplerine cevap vermek olarak siralanabilir. Bu nedenler ile araziler hem tarımsal üretim, hem de tarım dişı taleplerin karşılanması esnasında çeşitli düzeylerde ve farklı şekillerde degradasyona uğramaktadır.

Yoğun tarımsal üretimle beraber uygulanan kimyasal gübreleme ile zirai mücadele ilaçlarının kullanımı, ekim nöbetinin yeterince uygulanmamas1, arazi kullanım değişimi gibi toprak ve bitki yönetimi uygulamaları toprağın fiziksel, kimyasal ve biyolojik özellikleri üzerinde zamanla değişime neden olurlar (Chander ve ark., 1997; Liu ve ark., 2010). Yoğun tarımsal üretimde kültürü yapılan bitkilerden birisi de misırdır. Çanakkale ilinde 1995 y1lında Merkez - Özbek köyünde 285 dekarlık alanda başlayan tohumluk misır üretimi günü-müzde 40000 dekar alanın üzerinde bir alanda gerçekleştirilmektedir (Anonim, 2016).
Misır ve misır ürünlerine olan taleplerin hızla artmasıyla tohumluk mısır üretiminde de hızla artış meydana gelmiştir. Çanakkale ili, Karamenderes ovasında yaklaşık 25 yıldır tohumluk mısır yetiştiriciliği yapılmaktadır. $\mathrm{Bu}$ arazilerin bazılarının ard arda uzun yıllar boyunca misir bitkisi ekilerek kullanıldığı bilinmektedir. Mısır bitkisinin aynı arazi üzerine ard arda ekilerek tarımının yapılması uzun yıllar içinde o toprakların fiziksel, kimyasal ve biyolojik özelliklerinde değişiklikler meydana gelmesine neden olabileceği bildirilmiştir (Lal, 1997). Ayrıca, tarımsal üretimde uzun süreli olarak gübre ve pestisit gibi tarımsal-kimyasalların aşırı uygulamaları nedeniyle topraklarda ağır metal birikimi meydana gelebilmektedir. Uzun süreli ve eşzamanlı gübre uygulamasının toprakta ve bitkilerde yüksek metal birikimi gösterdiği birçok çalışma ile rapor edilmiştir (Parkpian ve ark., 2003; Lambert ve ark., 2007; Atafar ve ark., 2010; Jiao ve ark., 2014). Özellikle mısır üretiminde daha fazla ürün alabilmek için çok yüksek miktarlarda kimyasal gübre kullanılmaktadır. Bu uygulama sonucunda da toprakta besin maddelerinin dengesizliği meydana gelmektedir (Zhao ve ark., 2014).

Çalışma alanı olarak seçilmiş bölgede; yaklaşık 25 yıl önce başlayan tohumluk mısır tarımı, yoğun gübreleme ve ilaçlama yapılması ve ekim nöbetinin yapılmaması ile arazi degradasyonunun meydana gelmesi veya başlamış olması beklenmektedir. Ağır metallerin hareketliliği, toprağın bazı fiziksel ve kimyasal özelliklerinde meydana gelen değişimler, topraktaki biyoçeşitliliğin azalması ve erozyon gibi faktörlerde uzun yıllar içinde arazi degradasyonuna yol açmaktadır. Kasa ve ark. (2014), Arnavutluk'ta dört farklı arazi örtüsünün sulu ve kuru koşullardaki münavebesinin toprakların ağır metal düzeyine olan etkilerini incelemişlerdir. Çalışmalarında kontrol parseli (yonca), sulu koşullardaki araziler (araziler yılda 
altı ila sekiz kez sulanan, misır ve sebze ekili parsel) ve az sulanan araziler (yılda üç ila dört kez sulanan araziler, buğday, ayçiçeği, mısır) incelenmiştir. Çalışmanın sonucunda sulanan toprakların kadmiyum, krom ve nikel içeriği, sulanmayan toprağın içeriğinden önemli ölçüde daha yüksekken, kurşun içeriğinin (sulanan yerlerin üçünde), çinko ve arsenik içeriğinden (sulanan yerlerin birinde) önemli ölçüde daha düşük olduğu ortaya koyulmuştur. Zhao ve ark. (2014), kireçli bir toprakta 10 y1l boyunca sığır gübresi uygulanan ve tohumluk mısır ekilen bir alanda gerçekleştirdiği çalışmasında toprakların organik madde içeriği, toplam ve alınabilir bitki besin elementleri, $\mathrm{pH}, \mathrm{EC}$ (elektriksel iletkenliği) ve toprakların ağır metal içeriklerini incelemiştir. Çalışma sonucunda arazide ağır metallerin konsantrasyonunun arttığ 1 görülmüştür. Parihar ve ark (2016), Hindistan'da yedi yıldan fazla misır ekili kumlu tın ve farklı toprak işleme metotlarının uygulandığ 1 (Typic Haplustept) bir toprakta, suya dayanıklı agregat, hacim ağırlığ direnci gibi fiziksel özellikler ile organik karbon, mikrobiyal biyokütle ve enzimatik aktivitelerini araştırmıştırlar. Çalışmanın sonucunda geleneksel işleme yapılan parsele göre diğer alanlarda agregat stabilitesinin arttığı, hacim ağırlığ 1 ve penetrasyon direncinin düştüğü belirlenmiştir. Huang ve Jin (2008) sera, sebze ve buğday tarımı yapılan araziler üzerinde farklı arazi örtüsünden dolayı meydana gelen ağır metal kirliliğini incelemişlerdir. Sonuç olarak toplam $\mathrm{Zn}$ (Çinko) ve $\mathrm{Cu}$ (Bakır) içeriği, sebze arazisi ve sera arazisinde buğday tarımına kıyasla önemli ölçüde yüksek bulunmuştur. Ayrıca toplam Cd (Kadmiyum), $\mathrm{Pb}$ (Kurşun), $\mathrm{Cr}$ (Krom), As (Arsenik) ve Hg (Civa) içeriklerinin sebze arazisi ve sera arazisinde buğday arazisine kıyasla yükselme eğiliminde olduğunu bildirmişlerdir. Topraklardaki ağır metal kirliliği, ürün verimini ve kalitesini düşürebilir. Ürünlerdeki ağır metal birikmesi, gıda zinciri yoluyla insan sağlığı için potansiyel tehdide yol açabilir (Huang ve Jin, 2008). Çalıșma alanında bazı alanlarda uzun yıllardan beri yapılan mısır tarımı kimi bölgelerde monokültür tarım düzeyinde devam etmektedir.

Monokültür tarım sisteminde bitki kök bölgesinde bazı besin elementlerinin noksanlığ 1 veya fazlalığ oluşabilmektedir. Kök salgıları, çeşitli kimyasal ve biyolojik döngüleri etkileyerek ortamda katılım, kayıp ve dönüşümler oluşmasını sağlamaktadır. Bitki çeşidine göre farklılaşan bu etkileşim olumlu olduğu gibi olumsuz da olabilmektedir. Kayıpların yoğunlaştı̆ı alanlarda kimyasal gübre uygulamaları artmaktadır. Katılım, kayıp ve dönüşümler toprak ekosisteminde farklılaşmalara neden olmaktadır. Yapılan literatür araştırması bölge özelinde bu durum ile ilgili yapılmış herhangi bir çalışma bulunmadığını göstermiştir. Gerçekleştirilen bu çalışmanın literatüre katkı sağlanması hedeflenmiştir. $\mathrm{Bu}$ çalışmada, aynı fizyoğrafik ünite üzerinde ve benzer özellikte olan topraklarda arazi örtüsündeki değişime bağlı olarak oluşabilecek arazi degradasyon (fiziksel ve kimyasal özelliklerde değişimler) düzeyinin belirlenmesi amaçlanmıştır.

\section{MATERYAL ve YÖNTEM}

\section{Çalışma alanı}

Çalışma alanı, Çanakkale ili Merkez ilçesine bağlı Çıplak köyünde bulunan üç parselden (122 ada 9, 122 ada 8 ve 122 ada 6 no'lu) meydana gelmektedir (Şekil 1 ve Şekil 2). Her üç parselde Karamenderes nehri tarafından taşınıp depolanan alüviyal sedimentler üzerinde gelişmiş topraklardan oluşmaktadır. Parsellerin bulunduğu topraklar Karamenderes nehri sağ sahil taşkın düzlüğünde yer almaktadır. $\mathrm{Bu}$ topraklar Everest (2015) tarafından taşkın düzlüğü fizyografyası içerinde tanımlanmıştır. Alanda, Akdeniz ve Marmara bölgesinin geçiş iklimi bulunmakla birlikte çalışma alanında daha ziyade Akdeniz iklim özellikleri görülmektedir. Marmara ile Ege denizlerinin etkisinde kalan havzanın iklimi Akdeniz iklim tipine büyük benzerlik göstermektedir. Akdeniz ikliminden farklı olarak yağışlar kış aylarında fazla ve kış ayları Akdeniz iklimine kıyasla daha soğuktur. Yaz aylarında ise buharlaşma ve kuraklık Akdeniz iklimine göre daha azdır (Anonim, 2018). Çanakkale meteoroloji istasyonu verilerine göre (1960-2015) Çanakkale'nin y1llı ortalama toplam yağış miktarı $667 \mathrm{~mm}$, yıllık ortalama sıcaklığı 16 ${ }^{\circ} \mathrm{C}^{\prime}$ dir. 
T. EVEREST, A. SUNGUR, M. PARLAK, E. TEMEL, H. ÖZCAN: FARKLI ARAZI ÖRTÜSÜNÜN ARAZI DEGRADASYONU ÜZERINE ETKILLERİ: ÇANAKKALE ÇIPLAK KÖYÜ ÖRNEĞİ
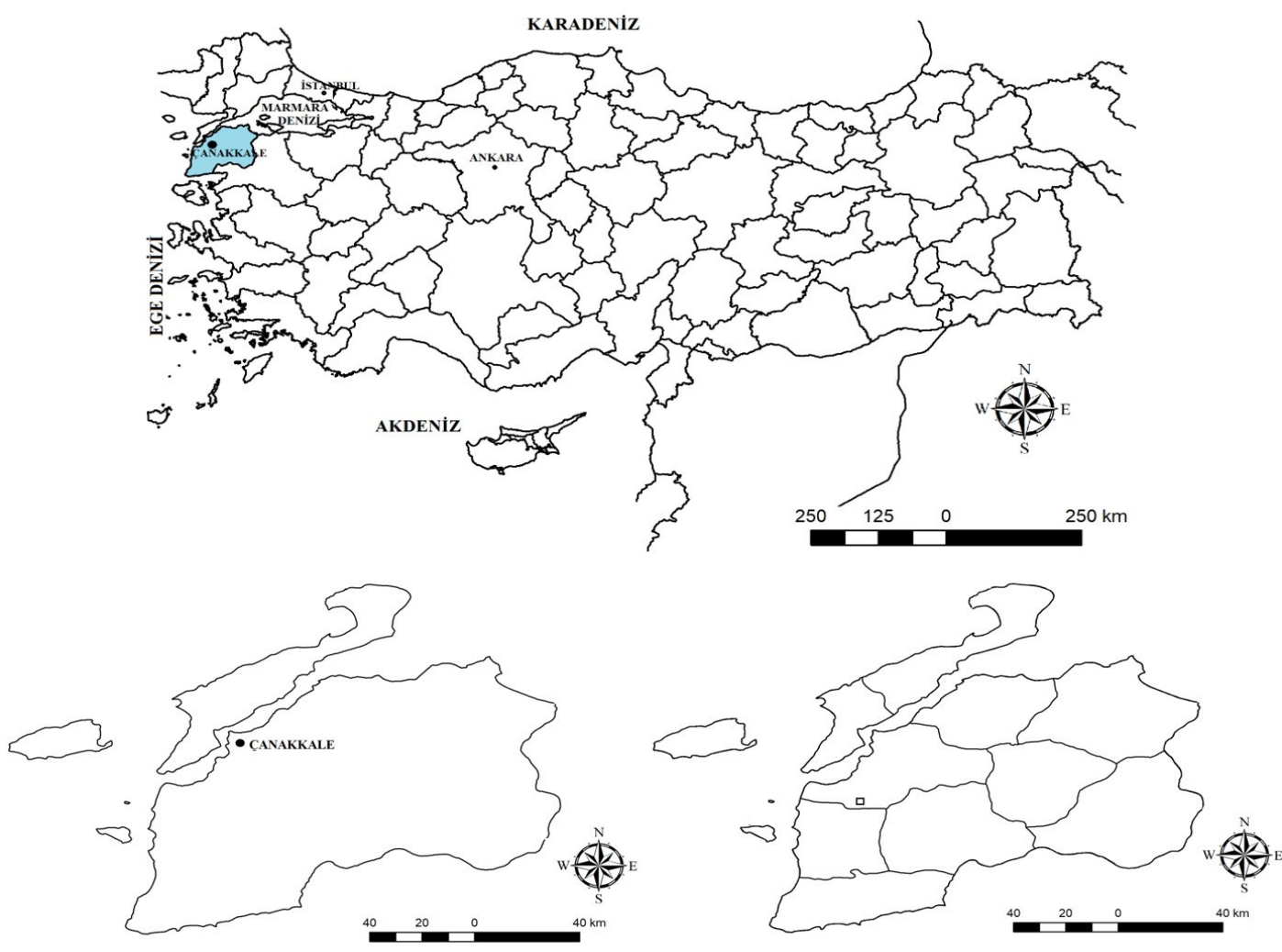

Şekil 1. Çalışma alanının lokasyon haritası.

Figure 1. Location map of study area.

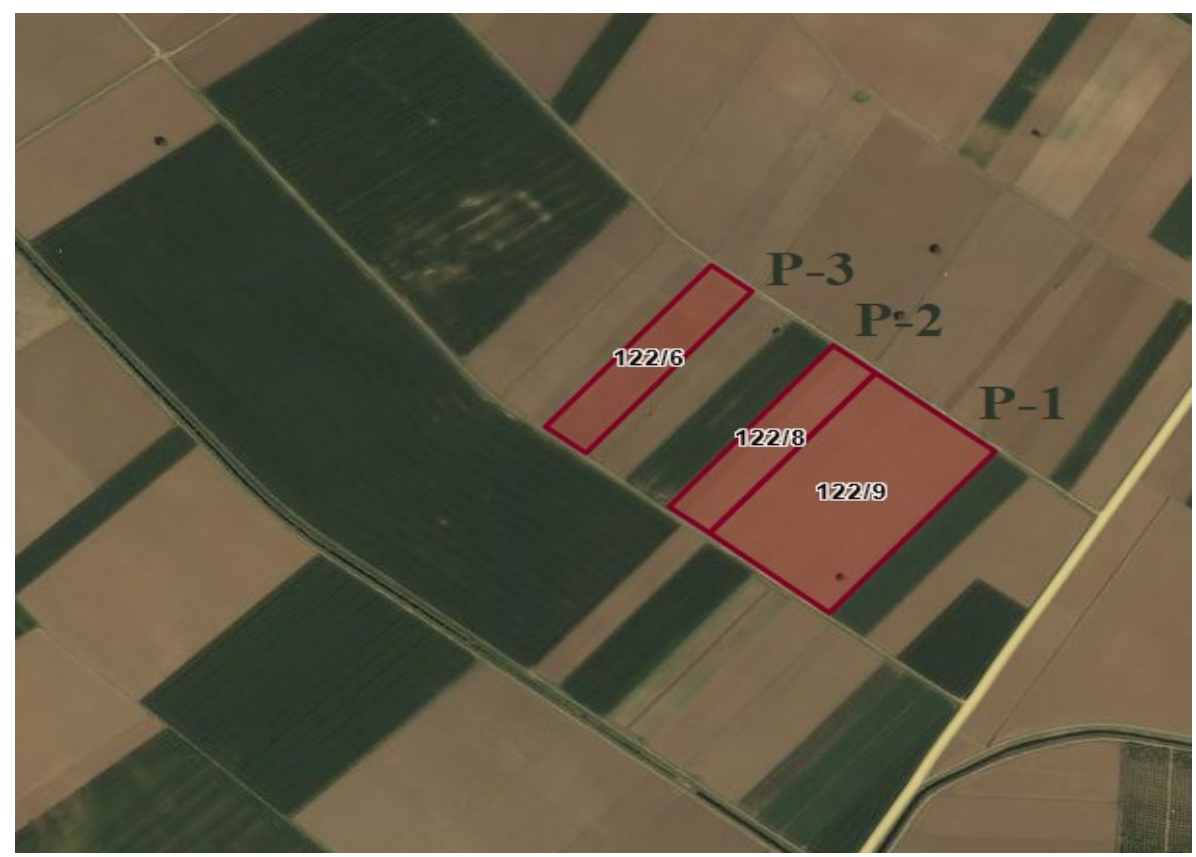

Şekil 2. Çalışmanın gerçekleştirildiği parseller.

Figure 2. Parcels used for the study. 
Çalışma amacı doğrultusunda taşkın düzlüğünde alüviyal sedimentler üzerinde oluşmuş toprakların yer aldığı aynı fizyografyada farklı arazi örtüsünün bulunduğu üç parsel seçilmiştir. $\mathrm{Bu}$ arazilere ait bilgiler Truva Sulama Birliği ve Tarım ve Orman Bakanlığı Çiftçi Kayıt Sistemi (ÇKS) kayıtlarından elde edilmiştir. $\mathrm{Bu}$ veriler doğrultusunda; 1 numaralı profilin açıldığ 122 ada 9 nolu parsel (P1) 15 yıldır art arda mısır yetiştirilen arazidir (Şekil 3). İki numaralı profilin açıldığı 122 ada 8 nolu parsel (P-2) son 7 yıldır art arda misır yetiştirilen bir arazidir (Şekil 4). Üç numaralı profilin açıldığı 122 ada 6 nolu parsel ise ayçiçeği-buğday, ayçiçeği-mısır, buğday-mısır gibi ikili ekim nöbeti yapılan bir arazidir (Şekil 5). Arazi çalışmaları misır bitkisinin hasadını takiben 25 Ekim 2018 tarihinde yapılmıştır. Kepçe (beko) ile açılan üç profil, Soil Survey Division Staff (1993)'deki esaslara göre tanımlanmıştır.

\section{Örneklerin alınması ve analize hazırlanması}

Açılan üç profilden bozulmuş ve bozulmamış toprak örnekleri alınarak laboratuvara getirilmiştir. Toprak örneklerini almak için metal olmayan aletler kullanılmış ve toprak örnekleri üzerinde örnek numaralarının yazılı olduğu plastik poşetlere koyularak güvenli bir şekilde laboratuvara ulaştırılmıştır. Ağır metal konsantrasyonlarının belirlenmesi için her parselden üç farkl1 derinlikten $(0-10,10-20$, 20-30 cm'den) toprak örnekleri alınmıştır. Örnekler laboratuvarda hava kurusu hale getirilmiştir. Hava kurusu hale getirilen topraklar tokmak ile dövülerek 2 mm'lik elekten geçirilmiştir.

\section{Toprak örneklerine ait fiziko-kimyasal özelliklerin belirlenmesi}

Toprak reaksiyonu $(\mathrm{pH})$ ve EC 1:2,5 (toprak: su) oranında hazırlanmış süspansiyonda $\mathrm{pH}$ metre ile okunmuştur (Grewelling ve Peech, 1960; Richards, 1954). Toprak bünyesi (tekstürü) Gee ve Bauder (1986) 'da belirtilen esaslara göre hidrometre yöntemi ile belirlenmiștir. Toprakların kalsiyum karbonat $\left(\mathrm{CaCO}_{3}\right)$ içerikleri Scheibler kalsimetresi kullanılarak belirlenmiştir (Nelson, 1982). Toprak örneklerinin organik madde kapsamları dikromat oksidasyon prosedürü ile belirlenmiştir (Nelson ve Sommers, 1982). Hacim ağırlığ $5,1 \mathrm{~cm}$ çap ve 5,0 cm yükseklikteki $100 \mathrm{~cm}^{3}$ hacimli çelik silindir ile bozulmamış toprak örneği alınarak Blake ve Hartge (1986)'da verilen ilkeler takip edilerek belirlenmiştir. Agregat stabilitesi ise mikro agregatlarda $(<0,25 \mathrm{~mm})$ Kemper ve Rosenau (1986) yöntemine göre saptanmıştır.

Toprak örneklerinde toplam $\mathrm{Cd}, \mathrm{Cr}, \mathrm{Cu}$, nikel (Ni), $\mathrm{Pb}$ ve $\mathrm{Zn}$ içeriklerini belirlemek için bir yaş yakma yöntemi olan kral suyu (Aqua regia) ekstraksiyon yöntemi kullanılmıştır. Yaş yakma yöntemi için; bir gram toprak örneği $100 \mathrm{ml}$ kapasiteli behere aktarılmış, $12 \mathrm{ml} \mathrm{kral} \mathrm{suyu}\left(\mathrm{HNO}_{3}: \mathrm{HCl}\right.$ karışımı, 1:3 oranında) ilave edilerek üzerine saat camı kapatılmış ve bir gece çeker ocak içerisinde bekletilmiştir. Daha sonra sıcak tabla (hot-plate) üzerine alınan örnekler sıcaklığın kademeli olarak artırılmasıyla kuruluğa yakın buharlaştırılmış ve bu işlem tekrarlanmıştır. Kral suyu ile çözeltiye geçen metallerin ölçümü için örnekler $0.45 \mu$ m'lik bir mavi bant filtreden geçirilmiş ve 25 ml'ye tamamlanmıştır. Çalışmada kullanılan kral suyu yönteminin doğruluğunu test etmek amaciyla sertifikalı referans madde (ERM-CC141, toprak) kullanılmıştır. Elde edilen geri kazanımlar \% 88,0 ile \% 109,7 aralığında olup sonuçların tatmin edici olduğu değerlendirilmiştir. Çalışma kapsamında hazırlanan ve ekstrakte edilen toprakların $\mathrm{Cd}, \mathrm{Cr}$, $\mathrm{Cu}, \mathrm{Ni}, \mathrm{Pb}$ ve $\mathrm{Zn}$ içerikleri ICP-OES (PerkinElmer, Optima 8000) cihazı kullanılarak belirlenmiştir.

\section{Ağır metal kirliliğinin değerlendirilmesi}

Metal kirliliğini değerlendirmek için Jeobirikim İndeksi (Igeo) kullanılmıştır. Igeo; zenginleşme ve metal kirliliğini nicel olarak değerlendirme için kullanılan bir indekstir (Muller, 1969). Igeo skalası Çizelge 1'de sunulmuştur. Igeo'nun hesaplanması için formül (1)'den faydalanılmıştır;

Igeo $=\log _{2}\left(\frac{c_{n}}{1,5 \cdot B_{g}}\right)$

Burada, $\mathrm{Cn}$; Örnekte okunan metal konsantrasyonu, 1,5; referans değeri matris düzeltmesi katsayısı ve $\mathrm{Bg}$; metalin litolojik referans değeridir. Litolojik referans değerleri Lide (2005)'in belirtmiş olduğu değerler esas alınarak belirlenmiştir. 
Çizelge 1. Igeo sınıflandırması.

Table 1. Igeo classification.

\begin{tabular}{llc}
\hline $\begin{array}{l}\text { Sinıf } \\
\text { Class }\end{array}$ & $\begin{array}{l}\text { Değer } \\
\text { Value }\end{array}$ & $\begin{array}{c}\text { Toprak kalitesi } \\
\text { Soil quality }\end{array}$ \\
\hline 0 & Igeo $\leq 0$ & Kirlenmemiş (Uncontaminated) \\
1 & $0<$ Igeo $<1$ & Kirlenmemiş / az kirlenmiş (Uncontaminated to moderately contaminated) \\
2 & $1<$ Igeo $<2$ & Az kirlenmiş (Moderately contaminated) \\
3 & $2<$ Igeo $<3$ & Az / fazlaca kirlenmiş (Moderately to strongly contaminated) \\
4 & $3<$ Igeo $<4$ & Fazlaca kirlenmiş (Strongly contaminated) \\
5 & $4<$ Igeo $<5$ & Fazlaca / Son derece yüksek kirlenmiş (Strongly to extremely strongly contaminated) \\
6 & $5<$ Igeo & Şiddetli düzeyde kirlenmiş (Extremely contaminated) \\
\hline
\end{tabular}

\section{BULGULAR ve TARTIŞMA}

\section{Toprakların morfolojik ve fiziko-kimyasal özellikleri ile sınıflandırılması}

Çalışma kapsamında incelenen P1 profili, Çıplak köyü 122 ada 9 parsel numaralı parsel üzerinde açılmıştır. P1 profilinin açıldığ 1 arazi $36,541 \mathrm{da}$ büyüklüğünde olup 15 yıldır art arda mısır tarımı yapılmaktadır. Parsel \% 0-2 eğimli olup arazide sulu tarım yapılmaktadır. Profilin drenaji iyi olup, yüzeyde taş bulunmamaktadır. P1 profilinde, taban suyu ile ilgili bir gösterge bulunmamaktadır. P1 profili, 436382 D - 4419148 K koordinatlarında açılmıştır. Parsel deniz yüzeyinden $18 \mathrm{~m}$ yüksekte bulunan fluviyal taşkın düzlüklerinde yer almaktadır. Profilin Ap horizonunda orta yoğunlukta saçak kök, AC horizonunda ise seyrek yoğunlukta saçak kök görülmüştür (Şekil 3). Arazi çalışmaları sırasında profilin özel görünümünde, $\mathrm{AC}$ horizonunun alt bölümü ve $\mathrm{C} 1$ horizonunda sıkışma not edilmiştir. Profil, Toprak Taksonomisine göre Typic Ustifluvents, WRB'ye göre ise Haplic Fluvisols olarak sinıfland1rılmıştır. P1 Profiline ait fiziksel ve kimyasal analiz sonuçlarını içeren veriler Çizelge 2'de sunulmuştur.
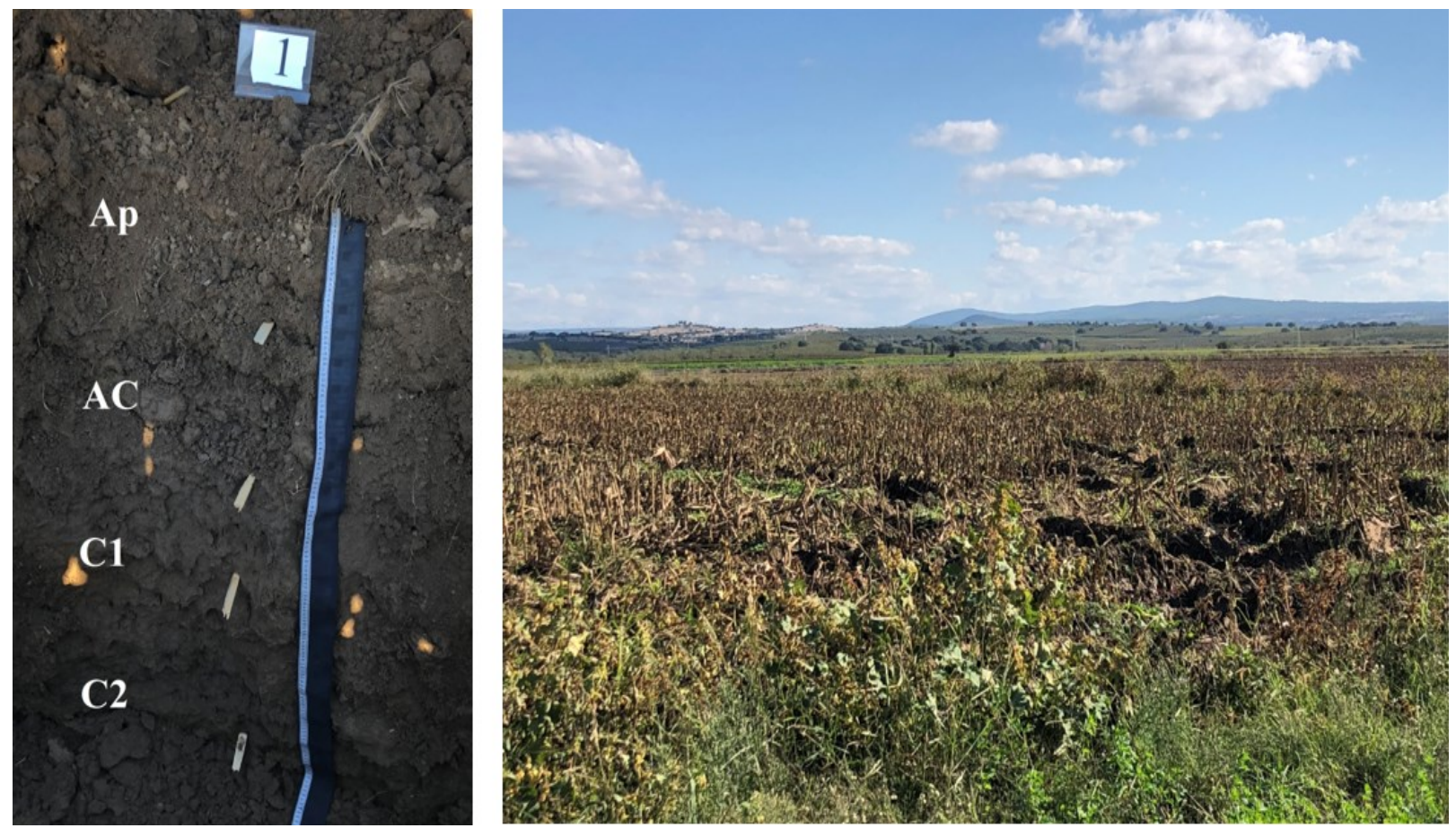

Şekil 3. P1 profili.

Figure 3. P1 profile. 
Çizelge 2. P1 Profiline ait fiziksel ve kimyasal analiz sonuçları.

Table 2. Physical and chemical analysis results of P1 profile.

\begin{tabular}{|c|c|c|c|c|c|c|c|c|c|c|c|}
\hline 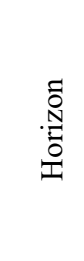 & 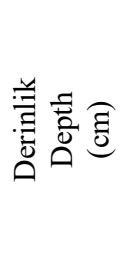 & 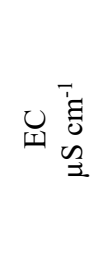 & $\stackrel{\mathbb{I}}{2}$ & $\int_{\tilde{e}}^{\infty} \overbrace{}^{\varrho}$ & 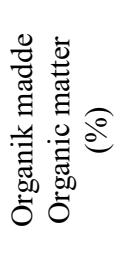 & $\bar{\nabla} \overline{0}$ & $=\widehat{0}$ & 寻胥 & 窟导 & 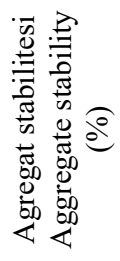 & 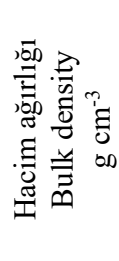 \\
\hline Ap & $0-27$ & 95,2 & 8,27 & 2,85 & 2,14 & 24,70 & 28,63 & 46,67 & $\mathrm{~L}$ & 94,43 & 1,29 \\
\hline $\mathrm{AC}$ & $27-57$ & 113 & 7,94 & 2,37 & 1,24 & 24,78 & 26,67 & 48,55 & $\mathrm{~L}$ & 92,69 & 1,45 \\
\hline $\mathrm{C} 1$ & $57-85$ & 110,4 & 8,34 & 1,71 & 0,98 & 18,51 & 22,43 & 59,06 & SL & 94,35 & 1,46 \\
\hline $\mathrm{C} 2$ & $85-134$ & 160,5 & 8,35 & 3,10 & 0,18 & 20,59 & 32,69 & 46,72 & $\mathrm{~L}$ & 93,51 & \\
\hline
\end{tabular}

Profilin Ap horizonunun derinliği $27 \mathrm{~cm}$ olup sürekli olarak işlenmektedir. $\mathrm{Bu}$ profilde yüzey horizonundaki hacim ağırlığı ile AC horizonun daki hacim ağırlığı arasında diğer iki profile göre daha yüksek fark bulunmaktadır. AC horizonunda bariz bir şekilde sıkışma görülmektedir. Diğer iki profilde Ad horizonu mevcut iken bu profilde AC horizonu tanımlanması nedeniyle sıkışmış katman sembolü kullanılmamıştır. Monokültür tarım nedeniyle alt katmanlarda oluşan pulluk altı sıkışmış katman bu profilde A horizonu ile kiyaslandığında diğer iki profile göre en yüksek değere sahiptir. Yüzeyde hacim ağırlığ değerinin de bu üç profil içinde en düşük değere sahip olması öncelikli olarak toprak bünyesi ve ikincil olarak organik madde içeriği ile ilişkilidir. Profilin yüzeyinde EC değeri 95,2 $\mu \mathrm{S} \mathrm{cm} \mathrm{cm}^{-1}$ olup derinlere inildikçe artmakta ve $160,5 \mu \mathrm{S} \mathrm{cm}^{-1}$ değerine ulaşmaktadır. Profilin tuzluluk açısından herhangi bir problemi bulunmamaktadır. $\mathrm{P} 1$ profilinin $\mathrm{pH}$ değeri yüzeyde 8,27 olup AC'de azalmakta $(7,94) \mathrm{C} 1$ ve $\mathrm{C} 2$ horizonlarında artmakta ve 8,35 değerine ulaşmaktadır. Toprak $\mathrm{pH}$ değerleri değerlendirildiğinde yüzeyde ve yüzey altında alkalileşme eğilimi olduğu görülmektedir. Profilin yüzeyinde $\mathrm{CaCO}_{3}$ içeriği \%2,85 olup derinlere indikçe azalmakta, C2 horizonunda ise $\% 3,10$ 'dur. Organik madde içeriği yüzeyde $\% 2,14$ olup derinlikle azalarak \%0,18 değerine düşmektedir. Toprak bünyesi $\mathrm{C} 1$ horizonu (kumlu tın) hariç diğer tüm horizonlarda tındır. Agregat stabilitesi yüzeyde $\% 94,43$, diğer horizonlarda ise sirasiyla $\% 92,69, \% 94,35$ ve 93,51 dür. Hacim ağırlığı yüzeyde $1,29 \mathrm{~g} \mathrm{~cm}^{-3}$ yüzey altında sirasıyla $1,45 \mathrm{~g} \mathrm{~cm}^{-3}$ ve $1,46 \mathrm{~g} \mathrm{~cm}^{-3}$ tür.

Monokültür tarım yapılan bu profilde yüzey altı katmanlarında tın bünyesine rağmen önemli oranda bir sıkışma olduğu görülmektedir. On beş yıl uzun bir süre olmamasına rağmen $\mathrm{A}$ horizonuna göre önemli oranda artan hacim ağırlı̆̆ ve profilde gözlenen çok zayıf kök dağılımları profil içerisinde misır gibi kalın ve derin kök sistemine sahip bir bitkinin toprak sıkışması nedeniyle iyi gelişim sağlayamadığının bir göstergesidir.

P2 profili Çıplak köyü 122 ada 8 numaralı parsel üzerinde açılmıştır. P2 profilinin açıldı $\breve{g} 1$ arazi 12,569 da büyüklüğünde olup 7 yıldır art arda misır tarımı yapılmaktadır. Parsel \% 0-2 eğimli olup, arazide sulu tarım yapılmaktadır. Profilin drenaj1 iyi ve yüzeyde taş bulunmamaktadır. P2 profilinde taban suyu sorunu yoktur. P2 profili, 436294 D - 4419190 K koordinatlarında açılmıştır. Parsel deniz yüzeyinden $18 \mathrm{~m}$ yüksekte bulunan fluviyal taşkın düzlüğü üzerinde oluşmuş toprakları içermektedir. Profilin Ap horizonunda yoğun saçak kök, Ad ve AC horizonlarında ise çok seyrek saçak kök görülmüştür (Şekil 4). Profil toprak taksonomisine göre Typic Ustifluvents, WRB'ye göre ise Haplic Fluvisols olarak sınıflandırılmıştır. P2 Profiline ait fiziksel ve kimyasal analiz sonuçlarını içeren veriler Çizelge 3’te sunulmuștur. 

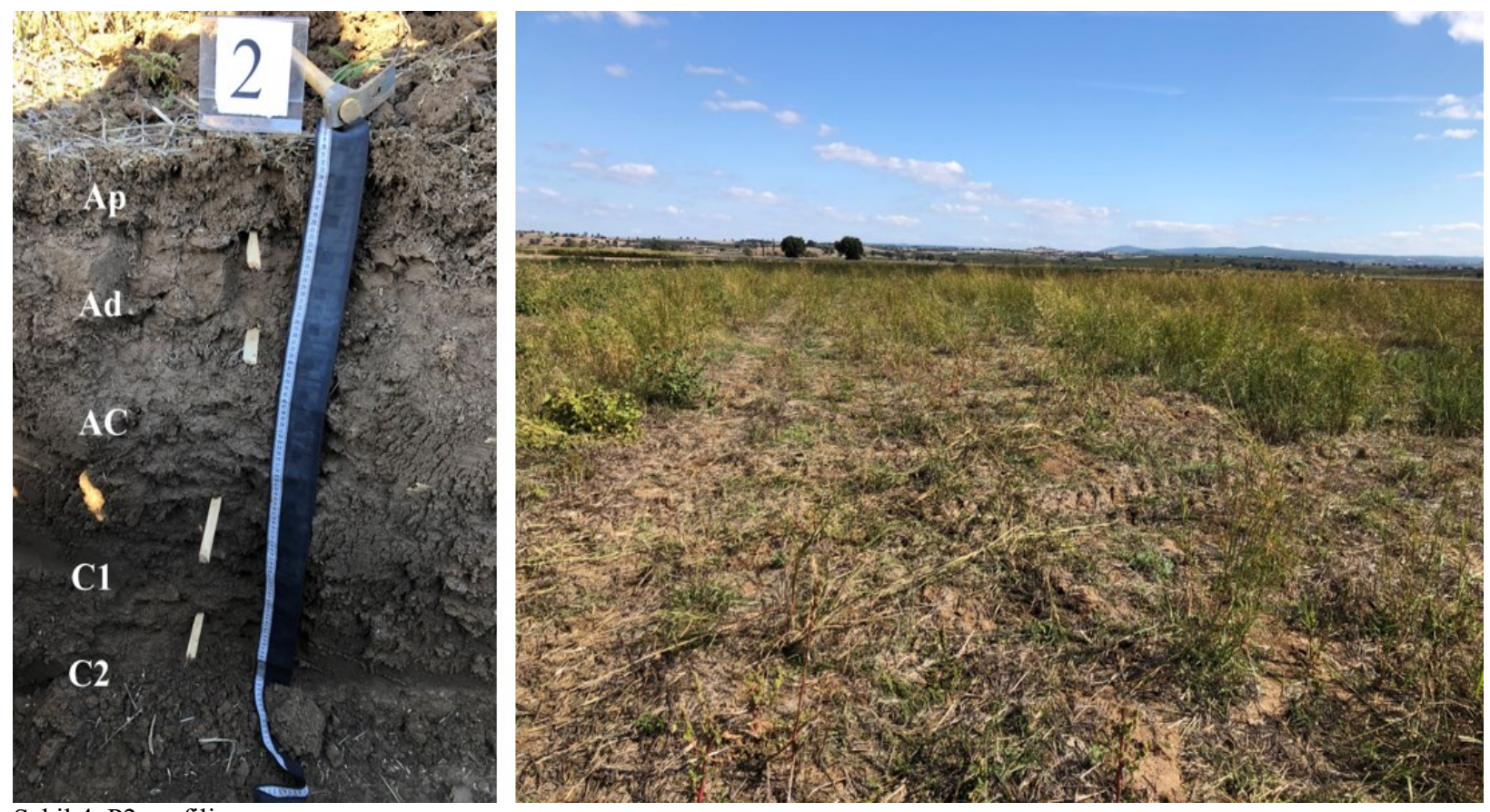

Şekil 4. P2 profili.

Figure 4. P2 profile.

Çizelge 3. P2 profiline ait fiziksel ve kimyasal analiz sonuçları.

Table 3. Physical and chemical analysis results of $\mathrm{P} 2$ profile.

\begin{tabular}{|c|c|c|c|c|c|c|c|c|c|c|c|}
\hline 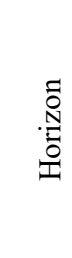 & 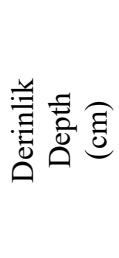 & 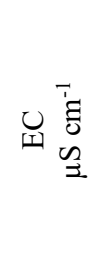 & $\frac{\pi}{2}$ & $\underbrace{\infty}_{\tilde{U}} \AA^{e}$ & 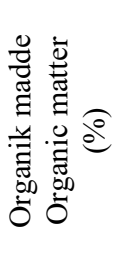 & 泣党 & $=\frac{0}{5}$ & 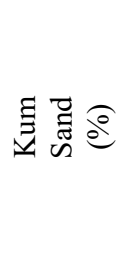 & 突总 & 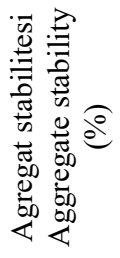 & 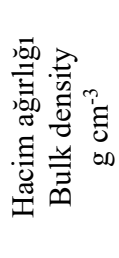 \\
\hline Ap & $0-12$ & 333 & 7,47 & 1,87 & 1,87 & 32,78 & 22,43 & 44,79 & $\mathrm{CL}$ & 95,04 & 1,50 \\
\hline Ad & $12-25$ & 401 & 7,65 & 2,21 & 1,58 & 30,90 & 24,59 & 44,51 & $\mathrm{CL}$ & 94,10 & 1,62 \\
\hline $\mathrm{AC}$ & $25-57$ & 180,4 & 8,06 & 2,38 & 1,41 & 33,05 & 22,61 & 44,34 & $\mathrm{CL}$ & 93,37 & 1,57 \\
\hline $\mathrm{C} 1$ & $57-89$ & 145,1 & 8,54 & 3,35 & 0,76 & 18,61 & 34,84 & 46,56 & $\mathrm{~L}$ & 94,44 & \\
\hline $\mathrm{C} 2$ & $89+$ & 142 & 8,76 & 6,55 & 0,46 & 16,37 & 16,21 & 67,42 & SL & 91,81 & \\
\hline
\end{tabular}

P2 profili; Ap-Ad-AC-C1-C2 horizon dizilimine sahiptir. Profilin Ap horizonu $12 \mathrm{~cm}$ olup, 12-25 $\mathrm{cm}$ arasinda bulunan Ad horizonunda pulluk alt1 sıkıșmıș katman bulunmaktadır. Ad horizonu arazideki çalışmalar sırasında spatülle ile kontrol edilerek profil tanımlama kartına kaydedilmiştir. $\mathrm{Bu}$ horizona ait hacim ağırlığı değeri de bu tanımlamay1 desteklemektedir $\left(1,62 \mathrm{~g} \mathrm{~cm}^{-3}\right)$. Profilde EC değerleri $142 \mu \mathrm{S} \mathrm{cm}^{-1}$ ile $401 \mu \mathrm{S} \mathrm{cm}^{-1}$ arasında değişmekte olup tuzluluk sorunu bulunmamaktadır. pH değeri yüzeyde 7,47 olup derine doğru artmakta ve C2 horizonunda 8,76 değerine ulaşmaktadır. $\mathrm{CaCO}_{3}$ içeriği yüzeyde
\%1,87 olup derinlere inildikçe artmakta ve C2 horizonunda $\% \quad 6,55$ değerine ulaşmaktadır. Organik madde ise yüzeyde $\% 1,87$ olup kademeli olarak azalmakta ve en altta bulunan C2 horizonunda \%0,46 dir. Ap, Ad ve AC horizonlarında yaklaşık $\% 30$ düzeyinde olan kil içeriği nedeniyle tekstür killi tın, $\mathrm{C} 1$ ve $\mathrm{C} 2$ horizonlarında kil oranına bağlı olarak tın ve kumlu tın bünye bulunmaktadır. Agregat stabilitesi değeri yüzeyde \%95,04 diğer horizonlarda ise sirasiyla $\% 94,10, \% 93,37$ ve 94,44 ve $\% 91,81$ tür. Hacim ağırlığı değeri tüm profilde yüksektir. Yüzeyde $1,50 \mathrm{~g} \mathrm{~cm}^{-3}$ yüzey altında ise $1,62 \mathrm{~g} \mathrm{~cm}^{-3}$ 
ve $1,57 \mathrm{~g} \mathrm{~cm}^{-3}$ tür. P1 profiline göre göreceli yüksekliğin nedeni organik madde ve kil içeriğindeki farklılaşmalardan kaynaklanmaktadır.

P3 profili, Çıplak köyü 122 ada 6 numaralı parsel üzerinde açılmıştır. P3 profilinin açıldığ 1 parsel, 12,318 da büyüklüğünde olup ayçiçeği-buğday, ayçiçeği-mısır ve buğday-mısır gibi ikili münavebe yapılan bir arazidir. \% 0-2 eğimli arazide sulu tarım yapılmaktadır. Profilde drenaj, taban suyu ve taşl11ık problemi bulunmamaktadır. P3 profili
436160 D - 4419278 K koordinatlarında açılmıștır. Parsel deniz yüzeyinden $18 \mathrm{~m}$ yüksekte bulunan fluviyal taşkın düzlüğünde yer almaktadır. Profilin Ap horizonunda seyrek saçak kök, Ad horizonunda ise çok seyrek saçak kök görülmüștür (Şekil 5). Profil Toprak Taksonomisine göre Typic Ustifluvents, WRB'ye göre ise Haplic Fluvisols olarak sınıflandırılmıştır. P3 Profiline ait fiziksel ve kimyasal analiz sonuçlarını içeren veriler Çizelge 4'de sunulmuştur.
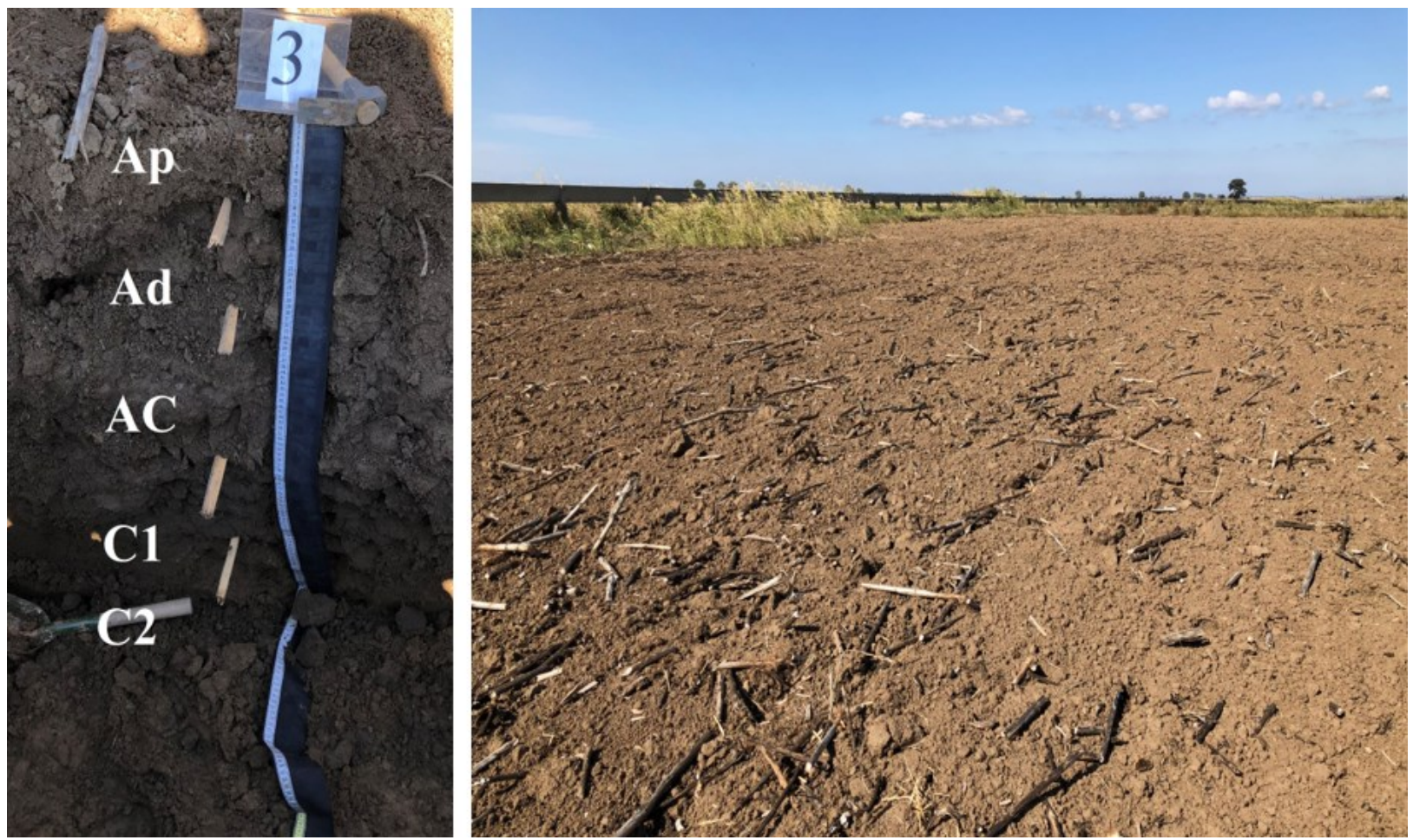

Şekil 5. P3 profili.

Figure 5. P3 profile.

Çizelge 4. P3 Profiline ait fiziksel ve kimyasal analiz sonuçları.

Table 4. Physical and chemical analysis results of $\mathrm{P} 3$ profile.

\begin{tabular}{|c|c|c|c|c|c|c|c|c|c|c|c|}
\hline 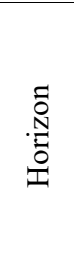 & 壭 & 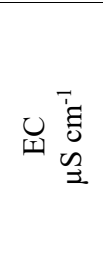 & $\frac{\pi}{2}$ & $\int_{\tilde{J}}^{\infty} \widehat{\varrho}$ & 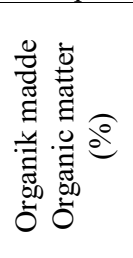 & $\bar{\nabla} \vec{d} \circlearrowright$ & $=\stackrel{0}{a}$ & 吾壹 & 菁䓂 & 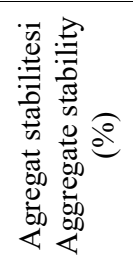 & 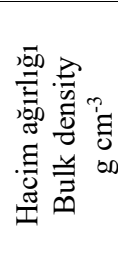 \\
\hline Ap & $0-11$ & 135,1 & 8,01 & 1,23 & 1,80 & 28,85 & 28,69 & 42,45 & $\mathrm{CL}$ & 95,83 & 1,39 \\
\hline Ad & $11-29$ & 175,9 & 8,05 & 2,29 & 1,48 & 24,73 & 32,75 & 42,52 & $\mathrm{~L}$ & 94,02 & 1,52 \\
\hline $\mathrm{AC}$ & $29-55$ & 108,8 & 8,42 & 0,41 & 1,28 & 24,93 & 24,77 & 50,30 & SCL & 82,33 & 1,48 \\
\hline 1 & $55-85$ & 609 & 7,85 & 1,96 & 0,76 & 24,78 & 24,61 & 50,61 & SCL & 70,49 & \\
\hline $\mathrm{C} 2$ & $85+$ & 439 & 8,55 & 4,71 & 0,44 & 16,44 & 14,24 & 69,32 & SL & 52,53 & \\
\hline
\end{tabular}


P3 profili, Ap-Ad-AC-C1-C2 horizon dizilimine sahiptir (P2 profili ile aynı horizon dizilimi ve aynı ana materyal üzerinde oluşmuş ve çok benzer özelliğe sahip olup toprak taksonomisinde aynı seri altında siniflandırılan topraklardır). Profilin Ap horizonu $11 \mathrm{~cm}$ olup, 11-29 $\mathrm{cm}$ arasinda bulunan Ad horizonunda sıkışma bulunmaktadır. $\mathrm{Bu}$ horizona ait hacim ağırlığı değeri de yüksektir $\left(1,52 \mathrm{~g} \mathrm{~cm}^{-3}\right)$. Profilin yüzeyinde EC değeri 135,1 $\mu \mathrm{S} \mathrm{cm} \mathrm{cl}^{-1}$ olup profil boyunca düzensiz değişmekte ve $\mathrm{Cl}^{\prime}$ 'de $609 \mu \mathrm{S} \mathrm{cm}{ }^{-1}$ değeri ile en yüksek seviyesine ulaşmaktadır. P3 profilinin yüzeyinde $\mathrm{pH}$ değeri 8,01 iken $\mathrm{C} 1$ horizonu hariç $(7,85)$ artmakta ve $\mathrm{C} 2$ horizonunda 8,55 değerine ulaşmaktadır. P3 profilinin yüzeyinde $\mathrm{CaCO}_{3}$ içeriği \%1,23 olup profil boyunca düzensiz bir dağ 11 lım göstererek $\mathrm{C} 2$ horizonunda \%4,71 değerine ulaşmaktadır. Organik madde içeriği yüzeyde $\% 1,80$, AC horizonunda $\% 1,28$ ve C2 horizonunda $\% 0,74$ değerindedir. Agregat stabilitesi değerleri sirasılyla \%95,83, \%94,02, $\% 82,33$ ve $\% 70,49$ ve $\% 52,53$ tür. Hacim ağırlığ değerleri yüzeyde $1,39 \mathrm{~g} \mathrm{~cm}^{-3}$ yüzey altında ise sirasiyla $1,52 \mathrm{~g} \mathrm{~cm}^{-3}$ ve $1,48 \mathrm{~g} \mathrm{~cm}^{-3}$ dir. Profilde yüzey altı katmanlarında sıkışma görülmektedir.

Çalışma alanında mısır tarımı yaklaşık 25 yıldır yapılmaktadır. Misır tarımı tohumluk üreten ve genellikle yurt dışı kökenli firmalar tarafindan üreticilere sözleşme karşılığı yaptırılmaktadır. Ürün dane misır ya da silajlık misıra kıyasla daha fazla gelir getirmesi, alım garantisi olması ve diğer ürünlere göre riskinin (pazarlama, fiyat dalgalanması vb) daha az olmasi üreticiler tarafindan da benimsenmiştir. Üreticiler bu arazilerde genellikle monokültür düzeyinde üretim yaparak bitkisel çeşitliliği kısıtlamaktadır. Üreticiler ile yapılan görüşmelerde arazilere istenen verimi almak için her yil artan miktarlarda kimyasal gübre ve pestisit kullandıkları bilinmektedir. Çalışma kapsamında 15 yıllık misır tarımı yapılan arazide diğer kullanımlara göre organik madde ve toprak tekstür avantajına rağmen daha fazla sıkışma ve hacim ağırlığında artış meydana gelmiştir. Sıkışma ve hacim ağırlığındaki artış topraklarda hidrolik iletkenlik, hava hareketi ve kök hareketini kısıtlayarak ürün kalite ve veriminde azalmalara neden olmaktadir.

\section{Toprakların toplam ağır metal durumu}

Toprak örneklerine ait toplam ağır metal içerikleri Çizelge 5'te sunulmuştur. Bütün değerler göz önüne alındığında ağır metallerin genel sıralaması $\mathrm{Ni}>\mathrm{Cr}>\mathrm{Zn}>\mathrm{Cu}>\mathrm{Pb}>\mathrm{Cd}$ şeklindedir. Elde edilen ağır metal sonuçları Alloway (1990) tarafından belirtilen tarım toprakları için genel yaygın değerler ile karşılaştırıldığında $\mathrm{Cu}, \mathrm{Ni}, \mathrm{Pb}$ ve $\mathrm{Zn}$ değerleri genel değerlerin üzerinde, $\mathrm{Cr}$ genel değerin altında ve $\mathrm{Cd}$ ise verilen genel değerlerin üst sınırına çok yakın olduğu görülmüştür. Diğer yandan Cd değerleri P1 $(10-20 \mathrm{~cm}$ ve $20-30 \mathrm{~cm})$, P2 $(0-10 \mathrm{~cm})$ ve P3 $(0-10 \mathrm{~cm}$ ve $10-20 \mathrm{~cm})$ 'de genel değerlerin üzerinde olduğu görülmüştür. $\mathrm{Bu}$ sonuçlar göz önüne alındığında çalışma alanında $\mathrm{Cu}, \mathrm{Ni}, \mathrm{Pb}, \mathrm{Zn}$ ve kısmen de $\mathrm{Cd}$ birikimi meydana geldiğine işaret etmiştir. Bu durum sadece mevcut kirliliği göstermekle kalmayıp ayrıca çalışma alanı topraklarının uzun süre devam eden bir biriktirme senaryosuna da işaret ettiği düşünülmüştür.

Kadmiyum ekosistemde çok ciddi sorunlara neden olabilir, çünkü oldukça hareketli ve toksik bir elementtir (Xue ve ark., 2018). Kadmiyum konsantrasyonları yüzey topraklarında $(0-10 \mathrm{~cm})$ en yüksek münavebenin olduğu parsel $>7$ yıl üst üste misır ekilen parsel $>15$ y1l üst üste misir ekilen şeklinde olduğu görülmüş̧ür (Çizelge 5). Bu eğilimin toprak sistemine yeni ilave olmuş tarımsal girdilerin (özellikle fosforlu gübreler) bir yansıması olduğu düşünülmüştür (Kubier ve ark., 2019). Diğer yandan derinlikle birlikte 15 y1l üst üste misır ekilen parselde Cd konsantrasyonun artış eğilimi sergilediği görülmüştür. Kadmiyum değerinin bu eğilimi mısır üretiminde diğer bitki türlerine göre daha fazla sulama suyu kullanılması ile açıklanabilir. $\mathrm{Bu}$ durum hareketli bir element olan Cd'un uzun vadede yüzeyden yıkanarak daha derinlerde birikim sergilediğine işaret etmiştir. $\mathrm{Cr}$ elementi iyonik potansiyeli çok yüksek olduğu için ayrışması çok zayıftır. Çalışmada $\mathrm{Cr}$ elementinin konsantrasyonları limit değerleri içindedir. Kromun konsantrasyonu incelendiğinde yüzeyde 
Çizelge 5. Toprak örneklerine ait toplam ağır metal konsantrasyonları $\left(\mathrm{mg} \mathrm{kg}^{-1}\right)$.

Table 5. Total heavy metal concentrations of soil samples $\left(\mathrm{mg} \mathrm{kg}^{-1}\right)$.

\begin{tabular}{lcccccc}
\hline $\begin{array}{l}\text { Örnekler } \\
\text { Samples }\end{array}$ & $\mathrm{Cd}$ & $\mathrm{Cr}$ & $\mathrm{Cu}$ & $\mathrm{Ni}$ & $\mathrm{Pb}$ & $\mathrm{Zn}$ \\
\hline P1 (0-10) & 0,99 & 81,40 & 40,08 & 120,23 & 40,24 & 60,29 \\
P1 (10-20) & 1,05 & 74,08 & 41,78 & 130,00 & 40,65 & 80,70 \\
P1 (20-30) & 1,16 & 83,53 & 42,38 & 114,68 & 39,32 & 57,68 \\
\hline P2 (0-10) & 1,03 & 80,36 & 47,07 & 132,98 & 38,86 & 66,71 \\
P2 (10-20) & 0,95 & 82,36 & 43,73 & 119,30 & 41,27 & 65,88 \\
P2 (20-30) & 0,99 & 76,20 & 43,40 & 124,28 & 37,04 & 74,45 \\
\hline P3 (0-10) & 1,05 & 84,39 & 43,96 & 115,78 & 35,48 & 66,16 \\
P3 (10-20) & 1,05 & 71,41 & 43,42 & 114,15 & 25,06 & 70,46 \\
P3 (20-30) & 0,95 & 56,96 & 41,18 & 126,65 & 35,20 & 57,58 \\
\hline Yaygın değer* & $0,2-1$ & $70-100$ & $20-30$ & 50 & $10-30$ & 50 \\
\hline
\end{tabular}

*: Tarımsal topraklar için genel yaygın değer (General common value for agricultural soils) (Alloway, 1990).

$(0-10 \mathrm{~cm})$ 'de en yüksek konsantrasyon ekim nöbetinin olduğu parsel daha sonra 15 yıl üst üste misır ekilen parselde ve en düşük 7 yil üst üste misır ekilen parsel olduğu görülmüsstür. Münavebenin olduğu parsel misır arazilerine göre daha az su kullanılan bir parseldir. Arazi kullanımının ve amenajman faaliyetlerine bağlı olarak ayrışan kromun bir kısmı sulama sularının etkisi ile alt katmanlara taşındığı düşünülmüştür. Nitekim uzun süre misır tarımı yapılan parselde kadmiyumda olduğu gibi krom konsantrasyonu derinlikle artmıştır. $\mathrm{Bu}$ sonuç yıkama ile taşınmanın bir göstergesidir. Kromun hareketsiz bir element olmasına rağmen 15 yıl üst üste misır ekilen parselde diğer iki parsele kıyasla göreceli olarak yüksek bulunmuştur.

Her ne kadar bazı çalışmalar topraktaki eser elementlerin derindeki katmanlara hareketini belirtmiş olsa da $\mathrm{Cu}$ ve $\mathrm{Pb}$ gibi çeşitli elementler organik madde ile güçlü ilişkileri nedeniyle yüzey toprağında birikebilmektedir (Banuelos ve Ajwa, 1999). Çalışma alanında Cu'nun konsantrasyonu 40.08-47.07 mg kg-1 arasında değişmiştir. Çalışma alanı topraklarında $\mathrm{Cu}$ elementinin ortalamalara göre kısmen yüksek olduğu ve bunun nedeninin tarımsal faaliyetler (pestisit ve gübreler) olduğu kanısına varılmıştır (Parlak ve ark., 2019; Zhang ve Wang, 2020). Bakır aynı zamanda bitkiler için mutlak gerekli bir besin elementidir, dolayısıyla farklı amenajman ve farklı bitki türlerinin örnekler arasında ki farklılaşmaya neden olabileceği düşünülmüştür. Kadmiyumun yan1 sıra $\mathrm{Ni}$, topraklarda hareketli ağır metallerden biri olarak kabul edilir. Nikelin toksisitesi Cd'a göre nispeten düşüktür, diğer taraftan Zn'e benzer şekilde fitotoksik konsantrasyonlara kolayca ulaşabilir (Sauerbeck ve Hein, 1991). Bütün örneklerde Ni konsantrasyonlarının Alloway (1990)'in bildirdiği kritik değerlerin üzerinde olduğu görülmüsstür. Çalışma alanında Ni'in konsantrasyonu 114.15$132.98 \mathrm{mg} \mathrm{kg}^{-1}$ arasında değişmektedir. Bu Ni konsantrasyonlarının çevre jeolojisi ile ilgili olabileceği ve özellikle serpantin kayaçlarından ayrışma ve çözünme yoluyla çalışma alanına taşındığı kanısına varılmıştır.

Kurşun bitkiler için toksik bir elementtir. Kurşun besin zincirine girdiğinde, kümülatif bir zehir olarak insan sağlığına zarar verebilir (Li ve ark., 2012). Kurşun hareket kabiliyeti düşük bir elementtir (Banuelos ve Ajwa, 1999). Çalışma alanında $\mathrm{Pb}$ konsantrasyonları 25,06-41,27 $\mathrm{mg} \mathrm{kg}^{-1}$ arasında değişmektedir. Alloway (1990)'ın bildirdiği kritik değerler göz önüne alındığında, çalışma alanı topraklarının $\mathrm{Pb}$ içeriği ortalamaların üstünde olduğu görülmektedir. Tarımsal girdilerle birlikte Karamenderes havzası içerisinde yer alan plütonik (başta granit olmak üzere) kayaçların ayrışma ürünlerinin nehir tarafından taşınıp depolanmasından kaynaklanabileceği düşünülmüştür. Çalışma kapsamında incelenen parsellerde $\mathrm{Zn}$ konsantrasyonlarının 57.58-80.70 mg kg-1 arasında değişmekte olup Alloway (1990) tarafından işaret edilen tarım toprakları için genel yaygın değerlerin $\left(50 \mathrm{mg} \mathrm{kg}^{-1}\right)$ üzerinde bulunmuştur. Bu fazlalık 
kurşun ve nikelde olduğu gibi amenajman ile birlikte havzanın jeolojisi ile ilgili olduğu kanısına varılmıştır. Kurşun, bakır ve çinko sülfür seven elementler grubunda olup granit gibi plütonik kayaçlarda fazla miktarda bulunmaktadır. Granitik kayaçların Karamenderes havzası üzerindeki etkisi Everest ve Özcan (2016 ve 2019) tarafindan da rapor edilmiştir. Ultrabazik kayaçlarda $\mathrm{Ni}$ ve $\mathrm{Cr}$ diğer elementlere göre daha fazla bulunmaktadır. Nitekim Karamenderes havzası içerinde önemli miktarda yüzeylenmiş ofiyolit ve ofiyolitlerin metamorfizması ile oluşmuş serpantinitler bulunmaktadır. Topraklardaki krom ve nikel yüksekliği bu jeolojik birimlerden gelen ayrışma ürünlerinden kaynaklanmaktadır (Özdeniz ve ark., 2017). Dolayısıyla çalışma alanı topraklarındaki ağır metal konsantrasyonlarının genel fazlalığının amenajman ile beraber havza jeolojisi ile ilişkili olduğu düşünülmektedir.

\section{Ağır metal kirliliğinin değerlendirilmesi}

Ağır metal kirliliğinin değerlendirilmesi amacıyla jeobirikim indeksi (Igeo) kullanılmıştır. Sonuçlar, çalışma alanındaki parsellerin $\mathrm{Cr}, \mathrm{Cu}$ ve $\mathrm{Zn}$ elementlerince kontamine olmadığını göstermiştir. $\mathrm{P} 1$ profilin $10-20 \mathrm{~cm}$ derinliğinden alınan örnek ve P2 profilin 0-10 $\mathrm{cm}$ 'den alınan örneklerin $\mathrm{Ni}$ elementince az kontamine olduğu görülmüştür. Buna karşıllk bütün profiller $\mathrm{Cd}$ elementince fazla, $\mathrm{Pb}$ elementince ise az kirlenmiş-kirlenmemiş olduğu görülmüştür (Çizelge 6). Igeo sonuçları $\mathrm{Cd}$ ve $\mathrm{Pb}$ elementleri için çevresel riskleri işaret etmektedir. Her iki elementin sergilediği bu birikim eğiliminin havza jeolojisinden etkilenebileceği gibi özellikle tarımsal kimyasalların (özellikle gübre ve pestisitler) bir yansıması olduğu kanısına varılmıştır. Tüm sonuçlar değerlendirildiğinde $\mathrm{Cd}$ ve $\mathrm{Pb}$ elementlerinin kirlilik potansiyeli yarattığı ve çevresel risk oluşturabileceğinden dolayı bu iki elementin izlenmesi, kontrol altına alınması ve daha detaylı çalışmaların yürütülmesi önerilmektedir.

\section{SONUÇ ve ÖNERILER}

$\mathrm{Bu}$ çalışma, Karamenderes Nehrinin taşıdığ 1 sedimentler üzerinde oluşmuş fluviyal taşkın düzlüğü fizyografyasında tanımlanan benzer özelliklere sahip topraklarda yürütülmüsstür. Çalışma kapsamında birbirine çok yakın fakat farklı arazi örtüsünün bulunduğu üç farklı parselde, toprakların degradasyon düzeyleri (fiziko-kimyasal özellikleri) üzerine etkileri incelenmiştir. Uzun yıllar aynı ürünün yetiştirilmesi ve aynı amenajman tekniklerinin kullanılması toprakların hacim ağırlığında bazı değişimlere neden olmuştur. Parsellerde açılan profillerin taksonomik incelenmesi sonucu 15 yıllık misir tarımı yapılan arazide (P1) önemli düzeyde sıkışma ve pulluk altı katman

Çizelge 6. Toprak örneklerinin Igeo'ya göre değerlendirilmesi. Table 6. Evaluation of soil samples according to Igeo.

\begin{tabular}{cccccccc}
\hline $\begin{array}{c}\text { Profil } \\
\text { Profile }\end{array}$ & $\begin{array}{c}\text { Sinir } \\
\text { Limit }(\mathrm{cm})\end{array}$ & $\mathrm{Cd}$ & $\mathrm{Cr}$ & $\mathrm{Cu}$ & $\mathrm{Ni}$ & $\mathrm{Pb}$ & $\mathrm{Zn}$ \\
\hline \multirow{2}{*}{1} & $0-10$ & $2,14^{\mathrm{c}}$ & $-0,74^{\mathrm{a}}$ & $-1,15^{\mathrm{a}}$ & $-0,07^{\mathrm{a}}$ & $0,94^{\mathrm{b}}$ & $-0,81^{\mathrm{a}}$ \\
& $10-20$ & $2,22^{\mathrm{c}}$ & $-1,05^{\mathrm{a}}$ & $-1,12^{\mathrm{a}}$ & $0,04^{\mathrm{b}}$ & $0,96^{\mathrm{b}}$ & $-0,38^{\mathrm{a}}$ \\
& $20-30$ & $2,36^{\mathrm{c}}$ & $-0,86^{\mathrm{a}}$ & $-1,08^{\mathrm{a}}$ & $-0,13^{\mathrm{a}}$ & $0,90^{\mathrm{b}}$ & $-0,86^{\mathrm{a}}$ \\
\hline \multirow{2}{*}{2} & $0-10$ & $2,20^{\mathrm{c}}$ & $-0,86^{\mathrm{a}}$ & $-0,94^{\mathrm{a}}$ & $0,08^{\mathrm{b}}$ & $0,89^{\mathrm{b}}$ & $-0,64^{\mathrm{a}}$ \\
& $10-20$ & $2,08^{\mathrm{c}}$ & $-0,88^{\mathrm{a}}$ & $-1,03^{\mathrm{a}}$ & $-0,07^{\mathrm{a}}$ & $0,98^{\mathrm{b}}$ & $-0,67^{\mathrm{a}}$ \\
& $20-30$ & $2,14^{\mathrm{c}}$ & $-1,00^{\mathrm{a}}$ & $-1,05^{\mathrm{a}}$ & $-0,01^{\mathrm{a}}$ & $0,82^{\mathrm{b}}$ & $-0,49^{\mathrm{a}}$ \\
\hline \multirow{2}{*}{3} & $0-10$ & $2,22^{\mathrm{c}}$ & $-0,86^{\mathrm{a}}$ & $-1,03^{\mathrm{a}}$ & $-0,12^{\mathrm{a}}$ & $0,76^{\mathrm{b}}$ & $-0,67^{\mathrm{a}}$ \\
& $10-20$ & $2,22^{\mathrm{c}}$ & $-0,73^{\mathrm{a}}$ & $-1,05^{\mathrm{a}}$ & $-0,13^{\mathrm{a}}$ & $0,25^{\mathrm{b}}$ & $-0,58^{\mathrm{a}}$ \\
& $20-30$ & $2,07^{\mathrm{c}}$ & $-1,43^{\mathrm{a}}$ & $-1,12^{\mathrm{a}}$ & $-0,01^{\mathrm{a}}$ & $0,75^{\mathrm{b}}$ & $-0,86^{\mathrm{a}}$ \\
\hline
\end{tabular}

a: kirlenmemiş (Uncontaminated), b: kirlenmemiş/az kirlenmiş (Uncontaminated / moderately contaminated), c:az /fazlaca kirlenmiş (Moderately contaminated / strongly contaminated). 
oluştuğu görülmüştür. Monokültür tarım yapılan bu arazide yüzey altı katmanının organik madde içeriği ve toprak bünyesine (tın bünye) rağmen beklenenin çok üstünde sıkışma ve hacim ağırlığında artış görülmüştür. Çalışma alanı topraklarında ağır metallerin önemli derecede litolojik kökenli olduğu buna karşı11k $\mathrm{Cd}$ ve kısmen $\mathrm{Pb}$ elementinin ise daha çok antropojik kaynaklı olduğu düşünülmüştür. Kadmiyum elementinin total konsantrasyon değerleri de her üç profil içinde kritik değerlerin üzerinde bulunmuş ve çalışma alanı topraklarının kadmiyumca kirlendiğini

\section{LITTERATÜR LİSTESİ}

Alloway, B. J. 1990. Heavy metals in soils. Blackie Academic and Professional. Glasgow.

Anonim. 2016. T.C. Tarım ve Orman Bakanlığı Çanakkale İl Tarım ve Orman Müdürlüğü Brifing Raporu.

Anonim. 2018. T.C. Tarım ve Orman Bakanlığı Meteoroloji Genel Müdürlügü, İllere ait istatistikler.

Atafar, Z., A. Mesdaghinia, J. Nouri, M. Homaee, M. Yunesian, M. Ahmadimoghaddam, and A. H. Mahvi. 2010. Effect of fertilizer application on soil heavy metal concentration. Environmental Monitoring and Assessment 160 (1-4): 83.

Banuelos, G. S., and H. A. Ajwa. 1999. Trace elements in soils and plants: an overview. Journal of Environmental Science \& Health Part A 34 (4): 951974.

Blake, G. R., and K. H. Hartge. 1986. Bulk density. pp. 363382. In: A. Klute $(E d)$. Methods of Soil Analysis, Part 1 Physical and Mineralogical Methods, 2nd Edition, Agronomy Monograph 9, American Society of Agronomy Soil Science Society of America, Madison.

Chander, K., S. Goyal, M.C. Mundra, and K. K. Kapoor. 1997. Organic matter, microbial biomass and enzyme activity of soils under different crop rotations in the tropics. Biol. Fertil. Soils (24): 306-310.

Doran, J.W., and T.B. Parkin. 1994. Defining and assessing soil quality. pp. 3-21. In: J.W. Doran et al., (ed.) Defining Soil Quality for a Sustainable Environment. SSSA Spec. Publ. No. 35, Soil Sci. Soc. Am., Inc. and Am. Soc. Agron., Inc., Madison, WI.

Everest, T. 2015. Truva Tarihi Milli Parkı arazilerinin detaylı toprak etüt ve haritalanması ile arazi değerlendirmesi. Doktora Tezi. Çanakkale Onsekiz Mart Üniversitesi Fen Bilimleri Enstitüsü. göstermiştir. Mısır örneğinde gerçekleştirilen bu pilot çalışmadan sonra gelecek araştırmalarda farklı arazi örtüsü dikkate alınarak daha geniş alanlarda çalışmaların yürütülmesi önerilmektedir.

\section{TEŞEKKÜR}

$\mathrm{Bu}$ çalışmayı FBA-2018-2576 kodlu proje ile destekleyen Çanakkale Onsekiz Mart Üniversitesi Bilimsel Araştırma Projeleri Koordinasyon Birimine teşekkürlerimizi sunarız.

Everest, T., and H. Özcan. 2016. The properties and comparison of the vertisol soils formed on different physiographies. PONTE 72 (12): 149-170.

Everest, T., and H. Özcan. 2019. Applying multivariate statistics for identification of groundwater resources and qualities in NW Turkey. Environmental Monitoring And Assessment 191 (2): 47.

Gee, G. W., and J. W. Bauder. 1986. Particle-size analysis. pp. 383-411.In: A. Klute (Ed). Methods of Soil Analysis, Part 1 Physical and Mineralogical Methods, 2nd Edition, Agronomy Monograph 9, American Society of Agronomy Soil Science Society of America, Madison.

Gibbs, H. K., and J. M. Salmon. 2015. Mapping the world's degraded lands. Appl. Geogr. (57): 12-21.

Grewelling, T., and M. Peech. 1960. Chemical Soil Test. Cornell University Agricultural. Expt. Sta. Bull, (960).

Huang, S. W., and J. Y. Jin. 2008. Status of heavy metals in agricultural soils as affected by different patterns of land use. Environmental Monitoring And Assessment 139 (1-3): 317.

Jiao, W., W. Ouyang, F. Hao, F.Wang, and B. Liu. 2014. Long-term cultivation impact on the heavy metal behavior in a reclaimed wetland, Northeast China. Journal of Soils and Sediments 14 (3): 567-576.

Kasa, E., P. Felix-Henningsen, R. A. Duering, and F. Gjoka. 2014. the occurrence of heavy metals in 1rrigated and non-1rrigated arable soils, NW Albania. Environmental Monitoring and Assessment 186 (6): 3595-3603.

Kemper, W. D., and R. C. Rosenau. 1986. Aggregate stability and size distribution. pp. 425-442. In: A. Klute (Ed). Methods of Soil Analysis, Part 1 Physical and Mineralogical Methods, 2 $2^{\text {nd }}$ Edition, Agronomy Monograph 9, American Society of Agronomy Soil Science Society of America, Madison. 
Kubier, A., R.T.Wilkin, and T. Pichler. 2019. Cadmium in soils and groundwater: A review. Applied Geochemistry 108: 304388.

Lal, R. 1997. Long-term tillage and maize monoculture effects on a tropical Alfisol in western Nigeria. II. Soil chemical properties. Soil and Tillage Research 42 (3): 161-174.

Lambert, R., C. Grant, and S. Sauve. 2007. Cadmium and zinc in soil solution extracts following the application of phosphate fertilizers. Sci Total Environ 378 (3): 293305.

Li, L., C. Zheng, Y. Fu, D. Wu, X. Yang, and H. Shen. 2012. Silicate-mediated alleviation of $\mathrm{Pb}$ toxicity in banana grown in Pb-contaminated soil. Biological Trace Element Research 145 (1): 101-108.

Lide, D. R. 2005. Abundance of elements in the Earth's crust and in the sea. CRC handbook of chemistry and physics. Internet Version 14-17.

Liu, E., C. Yan, X. Mei, W. He, S. H. Bing, L. Ding, Q. Liu, S. Liu, and T. Fan. 2010. Long-term effect of chemical fertilizer, straw, and manure on soil chemical and biological properties in northwest China. Geoderma 158 (3): 173-180.

Muller, G. 1969. Index of geoaccumulation in sediments of the Rhine River. Geojournal (2): 108-118.

Nelson, R. E., 1982. Carbonate and gypsum. pp. 181197.Methods of soil analysis. Part 2. Chemical and Microbiological Properties, (methods of soil analysis).

Nelson, D. W., and L. Sommers. 1982. Total carbon, organic carbon, and organic matter. pp 539-579. Methods of soil analysis. Part 2. Chemical and microbiological Properties, (methods of soil analysis).

Özdeniz, E., B.G. Özbey, L. Kurt ve A. Bölükbaş1. 2017. Serpantin ekolojisi ve Türkiye serpantin florası'na katkılar. Toprak Bilimi ve Bitki Besleme Dergisi 5(1): 22-33.

Parihar, C. M., M. R. Yadav, S. L. Jat, A. K. Singh, B. Kumar, S. Pradhan, D. Chakraborty, M. L. Jat, R. K. Jat, Y. S. Saharawat, and O. P. Yadav. 2016. Long term effect of conservation agriculture in maize rotations on total organic carbon, physical and biological properties of a sandy loam soil in North-Western Indo-Gangetic Plains. Soil and Tillage Research 161(8): 116-128.
Parkpian, P., S. T. Leong, P. Laortanakul, and N. Thunthaisong. 2003. Regional monitoring of lead and cadmium contamination in a tropical grazing land site, Thailand. Environmental Monitoring and Assessment 85 (2): 157-173. doi:10.1023/A: 1023638012736.

Parlak, M., T. Everest ve T. Tunçay. 2019. Rulo çim alanlarındaki toprakların ve çim bitkisinin bazı ağır metal $(\mathrm{Cu}, \mathrm{Zn}, \mathrm{Cr}, \mathrm{Ni}, \mathrm{Pb})$ içerikleri: pilot çalışmalar: Edirne, Balıkesir ve Çanakkale. ÇOMÜ Ziraat Fak. Derg. 7(2): 323-334.

Prăvălie, R., C. Patriche, and G. Bandoc. 2017. Quantification of land degradation sensitivity areas in Southern and Central Southeastern Europe. New results based on improving DISMED methodology with new climate data. Catena 158: 309-320.

Richards L. A., 1954. Diagnosis And İmprovement of Saline And Alkali Soils. U.S. Department Of Agriculture Handbook 60: 94.

Salih, A. A., E.T. Ganawa, and A. A. Elmahl. 2017. Spectral mixture analysis (SMA) and change vector analysis (CVA) methods for monitoring and mapping land degradation/desertification in arid and semiarid areas (Sudan), using Landsat imagery. The Egyptian Journal of Remote Sensing and Space Science (20): 21-29.

Sauerbeck, D. R., and A. Hein. 1991. The nickel uptake from different soils and its prediction by chemical extractions. Water, Air, and Soil Pollution, 57 (1): 861871.

Soil Survey Division Staff. 1993. Soil survey manual. USDA. Washington.

Xue, Y., W.J. Peijnenburg, J. Huang, D. Wang, and Y. Jin. 2018. Trophic transfer of Cd from duckweed (Lemna minor L.) to tilapia (Oreochromis mossambicus). Environ. Toxicol. Chem. 37(5): 1367-1377.

Zhang, Q., and C.Wang. 2020. Natural and human factors affect the distribution of soil heavy metal pollution: a review. Water, Air,\&Soil Pollution 231: 350.

Zhao, Y., Z. Yan, J. Qin, and Z. Xiao. 2014. Effects of longterm cattle manure application on soil properties and soil heavy metals in corn seed production in Northwest China. Environmental Science and Pollution Research 21 (12): 7586-7595. 